\title{
Corrigendum: Involvement of Polyamine Oxidase-Produced Hydrogen Peroxide during Coleorhiza-Limited Germination of Rice Seeds
} Bing-Xian Chen, Wen-Yan Li*, Yin-Tao Gao, Zhong-Jian Chen, Wei-Na Zhang, Qin-Jian Liu
and Zhuang Chen

Argo-biological Gene Research Center, Guangdong Academy of Agricultural Sciences, Guangzhou, China

Keywords: seed germination, polyamine oxidases, hydrogen peroxide, Oryza sativa, OsPAO5, gene expression, in silico analysis

\section{A corrigendum on}

OPEN ACCESS

Edited and reviewed by:

Vasileios Fotopoulos,

Cyprus University of Technology,

Cyprus

${ }^{*}$ Correspondence: Wen-Yan Li

liwy1023@foxmail.com

Specialty section This article was submitted to

Plant Physiology,

a section of the journal

Frontiers in Plant Science

Received: 02 December 2017 Accepted: 06 December 2017 Published: 12 December 2017

Citation:

Chen B-X, Li W-Y, Gao Y-T, Chen Z-J,

Zhang W-N, LiU Q-J and Chen Z

(2017) Corrigendum: Involvement of

Polyamine Oxidase-Produced

Hydrogen Peroxide during

Coleorhiza-Limited Germination of Rice Seeds. Front. Plant Sci. 8:2159.

doi: 10.3389/fpls.2017.02159
Involvement of Polyamine Oxidase-Produced Hydrogen Peroxide during Coleorhiza-Limited Germination of Rice Seeds

by Chen, B.-X., Li, W.-Y., Gao, Y.-T., Chen, Z.-J., Zhang, W.-N., Liu, Q.-J., et al. (2016). Front. Plant Sci. 7:1219. doi: 10.3389/fpls.2016.01219

Jun Liu was one of the authors in the original article. At present, the author himself requested to remove his name from the authorship. The correct version of authorship appears above.

\section{CHANGE IN AUTHOR CONTRIBUTION STATEMENT}

$\mathrm{B}-\mathrm{XC}$ and $\mathrm{W}$-YL conceived and designed the experiments, analyzed the data and wrote the paper; $\mathrm{B}-\mathrm{XC}$ and Y-TG performed all the experimental research and $\mathrm{W}$-YL carried out bioinformatics analysis and provided funding; $\mathrm{B}-\mathrm{XC}, \mathrm{W}-\mathrm{YL}$, and Z-JC critically revised the manuscript; W-NZ offered the help for photography; Q-JL, ZC for the revision of the manuscript. All authors read and approved the final manuscript.

The authors apologize for these errors and state that this does not change the scientific conclusions of the article in any way.

The original article has been updated.

Conflict of Interest Statement: The authors declare that the research was conducted in the absence of any commercial or financial relationships that could be construed as a potential conflict of interest.

Copyright $\odot 2017$ Chen, Li, Gao, Chen, Zhang, Liu and Chen. This is an open-access article distributed under the terms of the Creative Commons Attribution License (CC BY). The use, distribution or reproduction in other forums is permitted, provided the original author(s) or licensor are credited and that the original publication in this journal is cited, in accordance with accepted academic practice. No use, distribution or reproduction is permitted which does not comply with these terms. 